\title{
EU Security Challenges and Their Economic Implications
}

\author{
Dumitrache Vlad Ionut ${ }^{1}$, Constantinescu Maria ${ }^{2}$,
}

\begin{abstract}
:
Considering the volatile political, economic and security present environment, the European Union is currently facing more challenges than ever before in its existence. In addition to the challenges deriving directly from its status as a political-economical union of states, the EU is facing increasingly serious security challenges.

Some of these challenges are not new, such as those identified in the seminal document "A Secure Europe in a Better World' adopted by EU in 2010 (which singles out five key threats: terrorism, proliferation of weapons of mass destruction, regional conflicts, state failure, organized crime). Other security challenges have emerged more recently, such as illegal migration or the worsening of the relations with Russia.
\end{abstract}

Although the nature of these challenges is related to security and defense, many of them have economic implications and it is the purpose of this paper to analyze the complex interactions between the security and the economic challenges faced by the EU, and also by the individual member countries.

Keywords: challenges, defense, economic, expenditures, industry, security

JEL classification: $F 53$

\footnotetext{
${ }^{1}$ Regional Department of Defense Resources Management Studies, Brasov, Romania, vlad_dumitrache87@yahoo.ro

${ }^{2}$ Regional Department of Defense Resources Management Studies, Brasov, Romania, mconst_ro@yahoo.com
} 


\section{Introduction}

The European Union has greatly evolved over time, from a project of economic cooperation and integration to increased political cooperation and a framework for coordination in foreign and security policy. In time, the EU became an important player in the global economic and political environment, through what is essentially known as soft power - the use for the achievement of the established objectives of civilian instruments of power, such as foreign policy, culture, economic cooperation and development, foreign assistance, strategic communications etc. In recent years though, besides the more familiar challenges in terms of integration, economic growth, rise of the euro-skeptic movement etc, the EU has faced increasing security challenges, giving rise to the need to develop a common vision and unity of action in the area.

As a result, in 2003 the EU adopted a landmark document, the European Security Strategy - A Secure Europe in a Better World(Consilium Europa, 2003), aimed to provide this common vision and strategy, as a conceptual framework for the future Common Security and Defense Strategy. The document, similarly to a national security strategy, was aimed at analyzing the EU security environment, with its main security and defense threats, challenges and implications. The main five security threats identified were terrorism, proliferation of weapons of mass destruction (WMD), regional conflicts, state failure and organized crime. Five years later, the Report of the Implementation of the European Security Strategy: Providing Security in a Changing World(Report on the Implementation of the European Security, 2008) further confirmed the willingness of the EU to play a more active role in the area of security, while at the same time remaining a at a very generic and general level in regard to the ways ahead, using. In addition to the threats already identified in the European Security Strategy and which were still mentioned, other challenges were emphasized, such as illegal immigration, piracy, financial turmoil, global warming and environmental degradation.

The most recent official document dealing with the issue of the future common security and defense for the EU is the European Union Global Strategy, presented at the EU Summit on the $28^{\text {th }}$ of June 2016. The document was considered as the starting point of a more integrated EU policy on security and defense, a precursor of a European White Paper, but the moment of its issuing has been shadowed by the Brexit, considering that France and United Kingdom have been the driving forces behind a common vision of defense and security for the EU. Obviously, the document is not going to solve all EU's security and defense challenges, as it is a synthesis of previous years political trends, but on the same time it provides, for the first time, a clear doctrinal approach to EU's security and defense policy. It stated (at the very moment UK left the EU) the confidence in the EU model and values, together with a new resolve to develop strategic autonomy and autonomous capabilities - ambitious terms considering the history of the CSDP as far. 
Although the future of a more coordinated and effective CSDP is still unclear, while the security environment is getting more volatile and difficult of anticipate, the document is still important in identifying the challenges and setting the main action areas for the EU in terms of security and defense. The identification of challenges remains just the first step, as the most difficult task comes in getting all the EU members to have a common vision and strategy, to agree on the courses of action and, very important, to dedicate enough resources for the achievement of the identified goals, in the context of a stagnant EU economy and growing divergence within the members on the desired degree of integration and cooperation.

Besides the main threats to the EU security already identified in the previous documents, according to the EU Global strategy the current most pressing security challenges have both an external and internal dimension, ranging from terrorism, hybrid threats, cyber and energy security, organized crimes and external border management (in other words, the management of the illegal migration; A Global Strategy for the European Union's Foreign and Security Policy, 2016).

\section{EU Defense Spending}

The defense budgets of the EU members have been on a downtrend for many years, with the decline becoming more obvious after 2008, due to the effects of the economic crisis. Even before the onset of the crisis, the downturn in the defense spending of the EU countries was a reality, due to the perception of a safer environment, lack of clear threats to the security of EU member countries, the high costs of modern military capabilities, the fact that many EU members are already NATO members and their lack of willingness and coherence in creating a more credible European defense. After 2008, the financial crisis and austerity measures enforced in many EU countries further accentuated the decline in the overall defense expenditures, with a decrease of $10,5 \%$ in defense expenditures compared to the 2007 level and uneven and uncoordinated decreases in the defense budgets among EU members.

The decline in defense expenditures was not homogenous across the EU, as seen in the figure below. The largest decline was in the South Eastern Europe countries, especially considering the huge drop of $23,15 \%$ in Greece's defense expenditures in 2010, as a result of the austerity measures imposed. The decrease in Northern Europe countries was not as sharp, with a relatively stable trend, while Western Europe experienced sharper declines starting with the year 2011. 
Figure 1. Comparative regional defence spending in European Union (as \% of 2007)

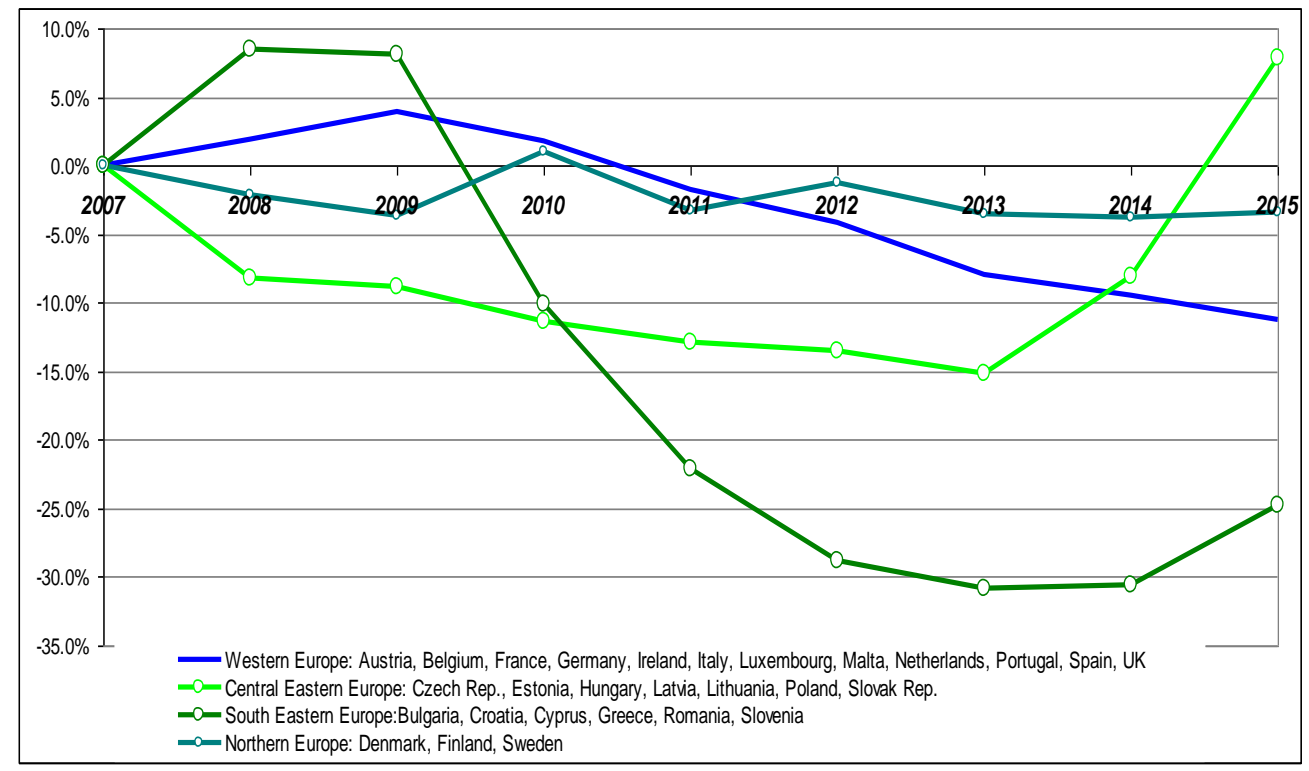

Source: SIPRI, https://www.sipri.org/databases/milex

However, due to the more recent security challenges, such as the concerns about Russian aggression in the east, the deterioration of the situation in Syria and Lybia giving rise to massive waves of illegal immigration, the wave of terrorist attacks on EU member countries, the downtrend seems to begin to reverse, starting with 2014. Economic considerations, related to the need to control budget expenditures, are increasingly challenged by the need to provide more convincing security and defense for the EU members, with the result of pledges from various EU governments to increase their defense spending in the coming years.

The increase in 2014, 2015 and 2016 appears to be the beginning of a new trend in the EU defense spending policy, with 31 European countries registering an estimated average of $8.3 \%$ increase in their defense budgets in 2016 compared to 2015 (Defense Budgets and Cooperation in Europe, 2016), though there are still marked differences between the regions.

Thus, according to the Stockholm Peace Research Institute data (SIPRI Military Expenditures Database, 2016), the Central and Eastern Europe and Southeastern Europe countries showed the most determined percentage increases in their defense budgets compared to previous years, followed by the Northern Europe countries at a slower rate, while the reversal of the downtrend for the Western European countries begins from 2016. 
Although the percentage increase seems spectacular for the Central, Eastern and Souther European countries, we have to keep in mind the differences in the size of the real defense budgets. Thus, the total defense spending of the Western Europe between 2007-2015 amounted to 259,313 million US\$, while the total defense spending of Central Eastern Europe was 15,856.54 million US\$ (that is $6.11 \%$ of the total defense expenditures of Western Europe), the total defense spending of South Eastern Europe was 13,301.18 million US\$ (that is $5.13 \%$ of the total defense expenditures of Western Europe), and the total defense spending of for Northern Europe was 14,446.41 million US\$ (that is $5.57 \%$ of the total defense expenditures of Western Europe, SIPRI Military Expenditures Database, 2016). The conclusion resulting from this data is that the main bulk of EU's defense spending is done by Western Europe and, considering the recent wave of terrorist attacks aimed at two of EU's biggest military spenders (France and Germany), together with the commitments expressed by the EU leaders in 2016 related to an enhanced security and defense policy, the increase in the 2016 defense budgets is expected to continue.

Figure 2. EU defense expenditures as \% of total EU expenses, 2015, in US \$m., at constant 2014 prices and exchange rates

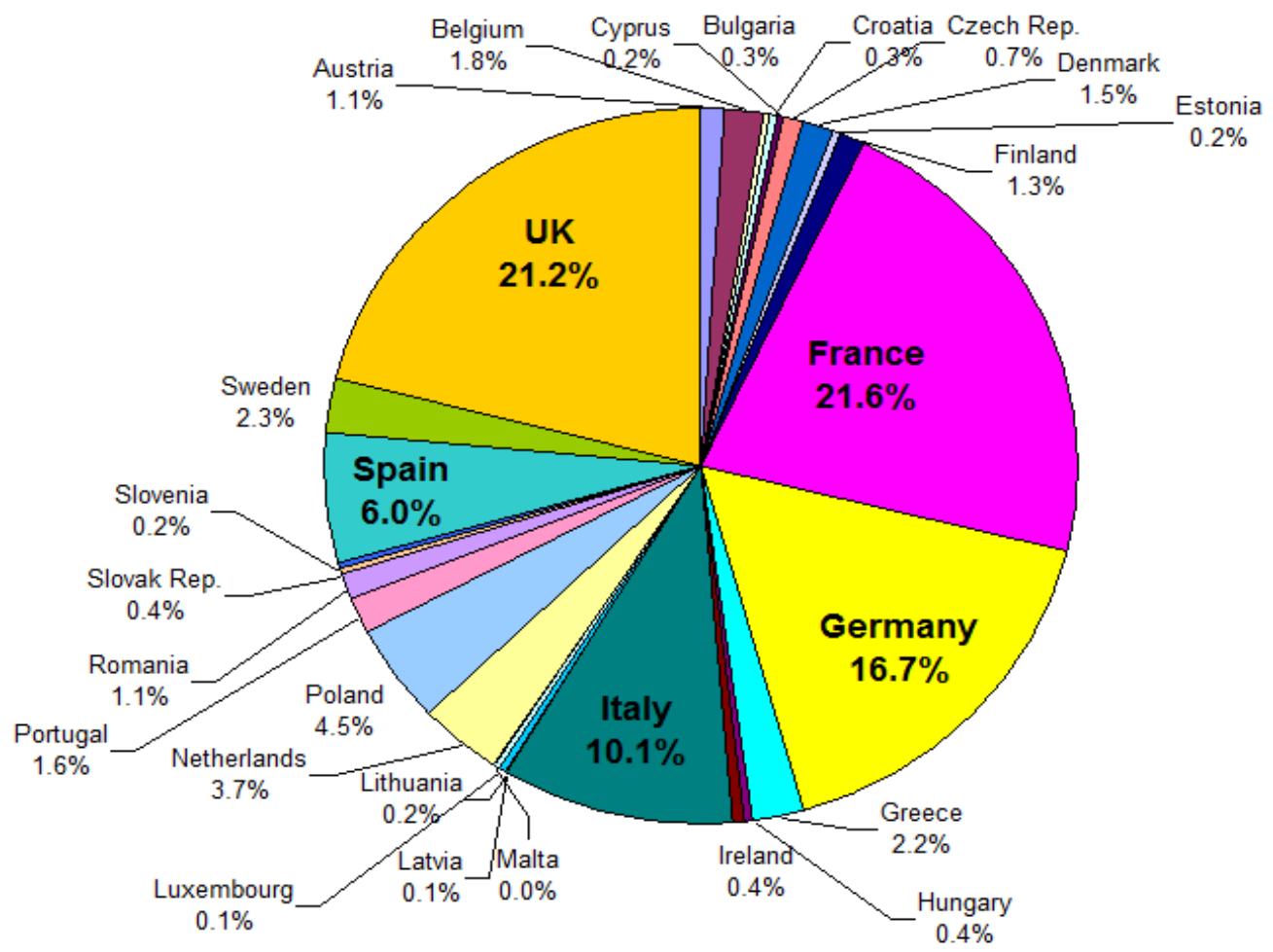

Source: SIPRI, https://www.sipri.org/databases/milex

As seen in the figure above, around $75.6 \%$ of the total defense expenditures of the EU countries are made up from the defense budgets of 5 countries: France, UK, 
Germany, Italy and Spain. In the light of the recent events regarding United Kingdom's decision to leave the EU, the remaining countries are faced with the challenge of increasing EU's defense capabilities and security credibility without one of the major defense spenders.

The European Union Global Strategy marks the a paradigm shift, from the soft power that was traditionally the hallmark of the EU towards hard power, in other words enhanced credibility in the area of security and defense and the emphasis on EU's ability to act autonomously. These goals are clearly linked to the need to "channel a sufficient level of expenditure to defence, make the most efficient use of resources, and meet the collective commitment of $20 \%$ of defence budget spending devoted to the procurement of equipment and Research \& Technology"( Shared Vision, Common Action: A Stronger Europe, 2016). The question that arises in this context is what exactly constitutes a sufficient level of expenditures, considering that the average defense expenditures of the EU countries do not exceed 1,4\% of GDP in 2015, with only two countries, France and the UK(SIPRI Military Expenditures Database, 2016), successfully maintaining their defense expenditures constantly above the 2\% of GDP recommended by NATO, between 2004 and 2015.

Figure 3. Evolution of EU defense spending, as average defense spending as \% of GDP and total defense spending in US \$ mil. at constant 2014 prices

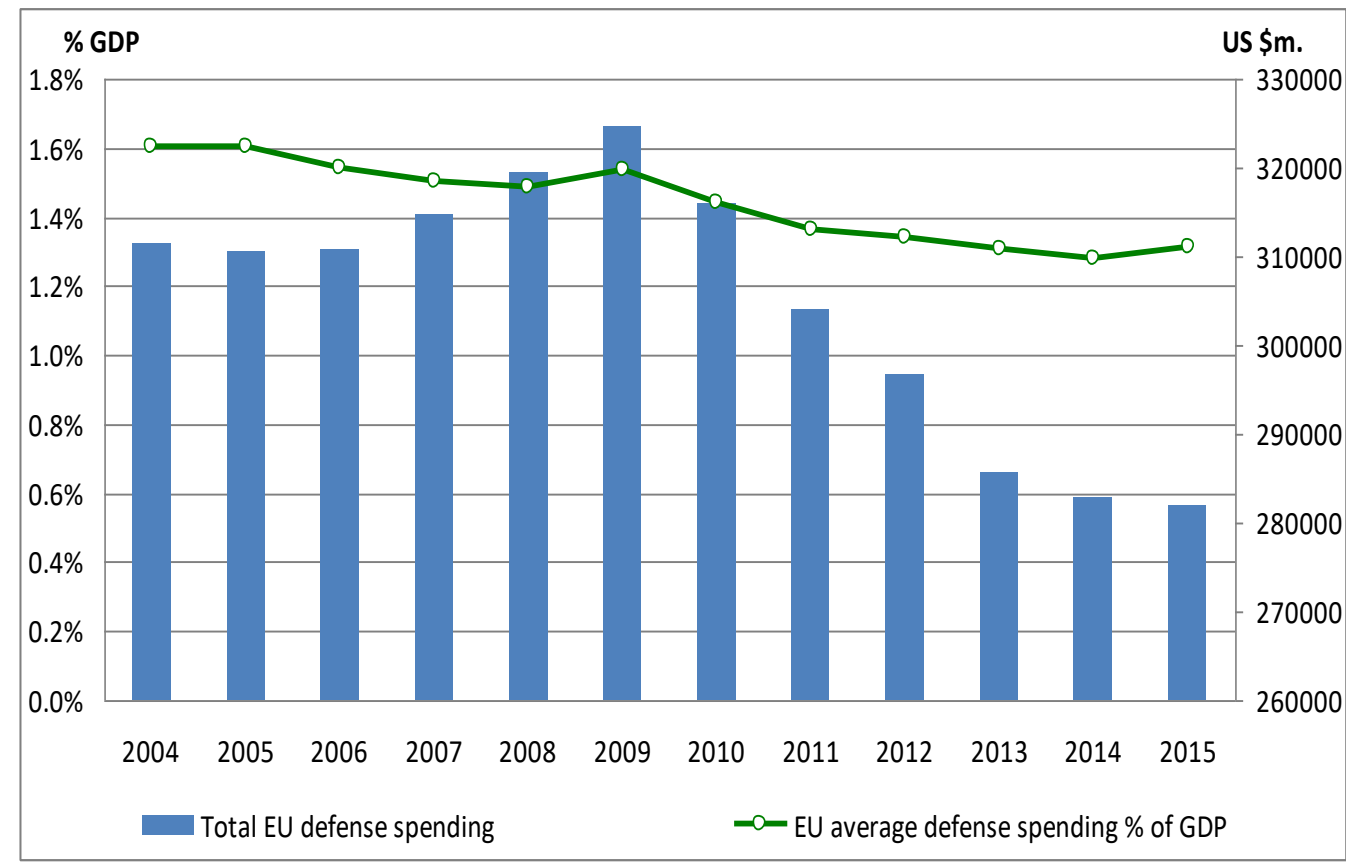

Source: SIPRI, https://www.sipri.org/databases/milex 
Figure 4. Evolution of EU members defense spending as \% of GDP

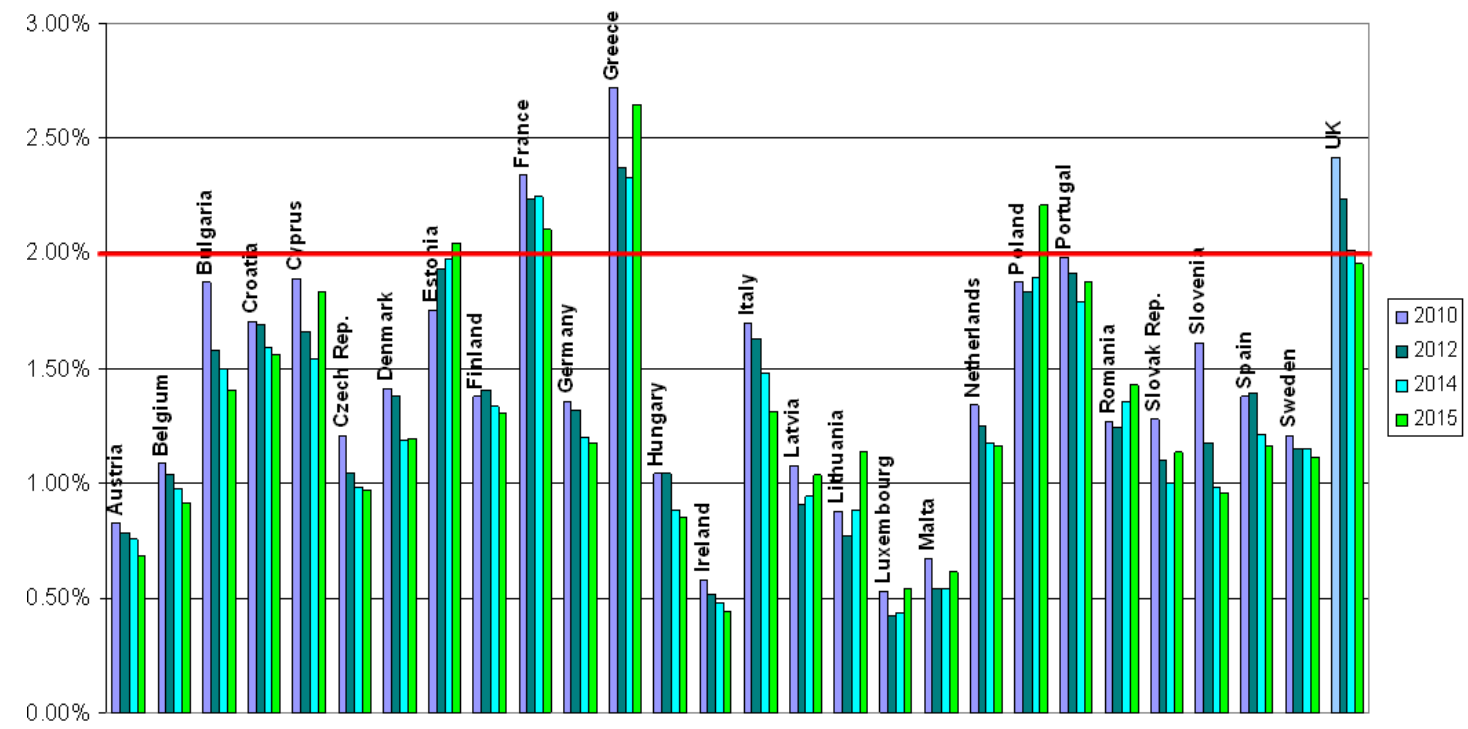

Source: SIPRI, https://www.sipri.org/databases/milex

\section{Security Challenges Impact on the European Defense Technological and Industrial Base}

The increase in the security and defense challenges faced by the EU could also have an effect on the European Defense Technological and Industrial Base (EDTIB), through a potential increase trend for defense expenditures and an increase willingness to enhance cooperation and to develop and maintain autonomous capabilities, but the size of this effect depends a lot on the concrete steps taken to implement what has been so far just political statements.

The concept of EDTIB emerged in 2000, as a response to the challenges faced by the defense area and defense industries across Europe, such as decreased defense budgets, rising costs of military equipment, high costs of research and development, increased competition on international markets, productive inefficiency and duplication. More recently, the EU Global Strategy states the importance of developing the EU defense industry in order to face the new security challenges "a sustainable, innovative and competitive European defense industry is essential for Europe's strategic autonomy and for a credible CSDP. It can also stimulate growth and jobs"( Shared Vision, Common Action: A Stronger Europe, 2016).

The concept of EDTIB It was based in the Letter of Intent (LoI) Framework Agreement Treaty signed by the defence ministers of the main defense producer countries in EU - France, Germany, Italy, Spain, Sweden and the UK. The agreement intended to create the political and legal framework necessary to facilitate industrial restructuring, to support the EDBIT, through 6 main areas of interest: 
security of supply, transfer/export procedures, security of information, research, treatment of technical information and harmonization of military requirements. The framework was further enhanced with the 2007 European Defence Technological and Industrial Base strategy and the "Defense Package", containing two key directives that constitute the foundation of EDTIB.

The European defense industry is a major industry sector, with sizeable contributions to the economic growth of some EU countries, as in 2014 it had a turnover of $€ 97,3$ billion (European Commision). It provides indeed an increasing number of direct jobs (from around 696000 in 2009 to 794695 in 2014, Aerospace and Defence Industries Facts \& Figures, 2014), but also indirect employment through its supply chain and subcontractors (up to 1,200,000 indirect jobs in 2014, European Commision), as there are more than 1350 small and medium-sized enterprises involved in this supply chain. The defense operators can range from large trans-national corporations (such as Airbus Group) to small and medium niche enterprises, involved from designing, producing and maintaining military equipment and subcomponents, to building military infrastructure. Although the main defense producers are mainly concentrated in six EU countries (France, Germany, Italy, Spain, Sweden, and the United Kingdom), companies from many EU countries supply various equipment and components to the industry.

Based on SIPRI data, out of top 50 arms exporting countries in the world, 18 are from EU, with an average of 25.70 percent of all the arms exports of the top 50 exporting countries for the period 2010-2015(SIPRI Arms Transfers Database, 2016). The 28 EU member states exported arms in the value of US\$ 7.97 billion (expressed in 1990 constant prices) in 2015, of which $21 \%$ ( $\$ 1.66$ billion) were towards other member states. Adding up the arms exports of the EU countries in the top 50 arms exporters, the total amount shows that the European countries become the second largest arms exporters after the United States.

Table 1. Total Arms Exports

Total arms exports from the top 50 largest arms exporters, 2010-2015, SIPRI Trend Indicator Values (TIVs) expressed in US\$ m. at constant (1990) prices

\begin{tabular}{|l|l|l|l|l|l|l|l|}
\hline Supplier & 2010 & 2011 & 2012 & 2013 & 2014 & 2015 & $\begin{array}{l}2010- \\
2015\end{array}$ \\
\hline Total top 50 & 25857 & 30239 & 28673 & 27282 & 28070 & 28626 & 168747 \\
\hline $\begin{array}{l}\text { Total European } \\
\text { Countries in top 50 }\end{array}$ & 6806 & 7973 & 5693 & 6781 & 8180 & 7941 & 43370 \\
\hline $\begin{array}{l}\text { Total European countries } \\
\text { in top 50 as \% of total 50 }\end{array}$ & 26.32 & 26.37 & 19.85 & 24.86 & 29.14 & 27.74 & 25.70 \\
\hline
\end{tabular}

Source: SIPRI Arms Transfers Database 2016

https://www.sipri.org/databases/armstransfers 
The trend in the EU arms exports has been on the decline by $23 \%$ (from one-third to one-fourth of global exports) in the interval 2011-2015 compared to the previous 5 years period, due to a complex combination of factors. The stated EU goal for strategic autonomy and freedom of action may provide a boost to the EU defense industry, provided that the member states will be willing and able to move beyond political statements into concrete actions. In more specific terms, strategic autonomy and freedom of action means, among other things, the ability to research, produce, operate, deploy, maintain, modify (and possibly sell) European capabilities and weapon platforms. This means a willingness to fund expensive research programs, cooperate in the area of arms production and finally to initiate acquisition programs and to allocate the required budgetary funds.

Considering that the EU economic growth is still sluggish, the EU members' commitments to increase strategic autonomy and the role of its security and defense component could have the potential to promote economic growth in the airspace and defense sector, plagued in the last decade by a shrinking defense budgets, fragmented markets and duplication. A lot of the equipments and technologies used by the military are increasingly dual-use, as they may have has both civilian and military applications, and there are no clear limits between defense and commercial companies. A potential increase in the acquisitions of military equipment and technologies in order to develop autonomous capabilities could have a positive economic effect, not only on the defense industry but also on other industrial areas.

Some encouraging initiatives have taken place in the field of EU security research, through the allocation of resources in the 2016-2017 Work Programme of Horizon 2020 for specific technologies and competences considered as dual use (such as Critical Infrastructure Protection - 20 million euro in 2016, Security - 113.25 million euro and Digital Security Focus Area - 29 million euro), amounting to a total around 164 million euro (The future of EU defense research, 2016).

The EU Global Strategy states that the focus of the EU defense is no longer only in terms of surveillance, monitoring or prevention, but that "Member States need all major equipment to respond to external crises and keep Europe safe. This means having full-spectrum land, air, space and maritime capabilities, including strategic enablers"( Shared Vision, Common Action: A Stronger Europe, 2016). On the other hand, the document acknowledges one of the main challenges related to the European defense, namely the fact that the defense acquisition programs tend to be mainly nationally oriented, and they are not enough to address the significant capability shortfalls. In this respect, the EU members are still lagging behind their targets, including the commitments undertaken at the previous Wales summit. According to some estimates (The future of EU defense research, 2016), the EU members should increase their total defense expenditure by US $\$ 87$ billion per year from the current level, and their equipment expenditure by US\$24.5 billion. 
At the same time, we have to keep in mind that the commitment expressed in the Global Security Strategy to encourage a strong defense industry does not automatically generate economic development and growth, and neither does the trend related to the increased defense budgets. The concept of increased autonomy underlines an idea stated in the years previous to the EU Global Strategy, namely the idea of a European Army. Put forward in political and military circles in the last years, the concept has both supporters and opponents, though it faces serious challenges due to its political implications, but also because its financial implications and questions related to its affordability.

As the European Army would not replace the national militaries, and considering that many EU members are also NATO members (which may lead to duplication of efforts), the financial effort of developing a functioning European Army does not appear to be sustainable on short term. Many EU members have not been able to attain the NATO $2 \%$ of GDP for defense expenditures, due to the inability of their economies to sustain such levels of defense budgets, but also due to the reluctance, from a political and social point of view, to dedicate large amounts of public money for what is perceived to be an unproductive sector. In total, EU members already spend 281 billion US\$ to finance their national armies and the defense expenditures, although on an increasing trend, are not to be expected to grow at the rate necessary to cover the financial needs of a more autonomous EU in the field of defense (SIPRI Military Expenditures Database, 2016). Also, an increase in the level of defense expenditures doesn't necessarily mean an increase in output - functioning military capabilities, improved training and interoperability etc. Without tackling some of the current challenges (ineffective and partisan national acquisition procedures and processes, large number of military personnel, large amount of money spent on maintaining and repairing outdated equipment etc), the defense budgets increases will not have significant positive effects either on the effectiveness of a common defense nor on the EU members economies.

One solution could be an increase in the efficiency of the current spending, by a more rational decision making process related to national spending, enhanced cooperation, avoidance of duplication of capabilities. A better distribution of the defense funds across the EU, engaging in collaborative programs and increased cooperation and interoperability could generate some savings, especially for some smaller countries, that could benefit from the logistical facilities of bigger defense spenders would have access to more modern technologies and training. Of course, much of the financial burden will probably continue to rest on the larger states, like France and Germany, which are already supporting much of the financial and operational burden of the EU military actions, especially since the Brexit. There are also potential benefits for these countries, considering that most part of the biggest defense companies are located in these countries and they may be able to ask for more support (operational and even financial) for operations such as the ones in Mali and Central Africa, from other EU member countries. 
Still, a better coordination and increased collaboration in defense and security remains a big challenge for the EU countries, as it requires moving beyond national interests towards a common European view, harmonization of defense planning processes, greater transparency on the level and destination of national defense spending, assuming the political and financial risk of getting involved in costly production cooperation programs with other states, deciding by common agreement on the capability targets, capabilities requirements (what capabilities are needed), shortfalls and surpluses and the best ways to cover/eliminate them etc. There are some encouraging first steps in this direction, through the defense spending reviews performed by most of the EU members or initiatives such as Pooling and Sharing.

Developed by the European Defense Agency in order to pool and share military capabilities, it produces initiatives such as such as the Air-to-Air Refuelling, the Helicopter Training Programme, maritime surveillance, or the EU Satcom Market procurement cell projects. Although in the beginning of 2015 there were 393 military projects under $\mathrm{P} \& \mathrm{~S}$, the results of the initiative are not spectacular, especially since it depends a lot on regional proximity and pre-existing political cooperation. The Pooling and sharing could have a positive impact on the European defense industry, by pooling together demand for weapons systems, pooling research and development and sharing industrial infrastructure, but this would require a more structured framework than the one already existing, making political decisions regarding the delicate balance between national defense autonomy and military effectiveness through cooperation, or by advancing the EU battlegroups towards the Framework Nation Concept.

Also, the EU already has in place the Athena Mechanism, designed to finance and administer the common costs of EU military operations, as according to the article 41 of the Treaty of the European Union, operations under the Common Foreign and Security Policy (CFSP) with military implications or in the field of defence cannot be covered by the EU budget. The costs that can be covered by this mechanism are detailed in the annexes of the Council Decision 2011/871/CFSP, and cover a wide variety of costs, such as HQ implementation and running costs, for forces as a whole - infrastructure, medical services (in theatre), medical evacuation, identification, acquisition of information (satellite images). The Athena Mechanism may also finance, but only at the request of the Operation Commander and following the approval by the Special Committee some infrastructure capabilities, essential additional equipment, medical services, or other critical theatre-level capabilities (demining, chemical, biological, radiological, and nuclear (CBRN) protection, storage and destruction of weapons, eur-lex.europa.eu).

This existing mechanism could be extended to cover common military capabilities, following the principles of NATO's NSIP program and the capabilities packages, with focus on a multi-year approach and the re-use of the funds not spend during one year. The fund could be financed (at the beginning, at least) on a voluntary basis, by those countries interested in deepening their European defense cooperation. 
Coordinating and integrating these two mechanisms could provide a step forward to an increased efficiency of the EU defense spending. Another possibility to improve the defense capabilities of the EU and the effectiveness of its operations, without a massive increase in national defense budgets could be the creation of European funds for security, defense or crisis management, in order to have a common fund for common European capabilities or operations, based on contributions of the member states. The idea is not revolutionary, considering that EU already has similar initiatives like the European Development Fund (aimed at providing development aid to African, Caribbean and Pacific (ACP) countries and to overseas countries and territories (OCTs), a fund outside the EU budget financed by direct contributions from EU members, based on a contribution key, governed by its own financial rules and composed of a multi-annual budget in amount of 30.5 billion euro for the period 2014-2020 (ec.europa.eu). The idea of a joint financing and the set up of other trust funds outside the EU Financial Regulation was considered to be necessary "to be further explored" in a report from the Political Military Group in 2014, but no further specific action took place. In this respect, the biggest European challenge in terms of defense and security remains the reluctance to forgo the national interests and the limitations of the national, economic and strategic interests or cultures (statewatch.org, 2014).

One of the more recent challenges to the future of the European Defense Technological and Industrial Base relates to United Kingdom's decision to leave the European Union. The uncertainty regarding the specific conditions of UK's exit may lead significant operational or export challenges for the European aerospace and defense firms which have a significant role in Britain, either by including British companies (such as the Airbus Group, MBDA missile systems) or having major operations in the UK (Leonardo-Finmeccanica, Thales).

Another area of concern related to the Brexit concerns the very important goal of the CSDP, increased cooperation in the field of defense projects. A lot of common European weapons development projects. For instance the Eurofighter Typhoon fighter is built jointly by a consortium of Britain's BAE Systems, Italy's Alenia Aermacchi and the multinational Airbus Group for France, U.K., Germany, and Spain.

The recent conflicts in Libya and Syria have determined the EU to reconsider its position and to act at different levels of governance. Other conflicts might at either local, national, regional or global dimensions might occur and therefore the need for a European Union Global Strategy is required. . The European Union considers that sustainable peace can only be achieved through comprehensive agreements rooted in broad, deep regional and international partnerships. For this a comprehensive approach to conflicts and crisis is need. The EU must use all common policies available. One of the key issues of the EU is to expand this "comprehensive approach" in years to come in order to make all EU members a part of a common security entity or capability. 
The need for such common policies reside in the ever growing challenges in security that the EU has to address, such as terrorism, cyber and energy security, organized crime, hybrid threats and external border management. The EU has to consider challenges with both internal and external dimensions. For example recent events that have required specialized EU agencies to enhance border protections and maritime security that have to fight cross-border crime, disrupt smuggling networks or even save more lives can benefit from the European Border and Coast Guard. These structures can operate under the Common Securities and Defense Policies (CSDP) missions and operations.

A second issue that the EU has to take into consideration is the investment in digital capabilities in order to secure data, networks and critical infrastructure within the European digital space. A EU Global Strategy should include digital services capabilities and products in cyber technologies, in order to enhance the European Union's resilience.

\section{Terrorism Challenges to the European Union Security}

One of the most significant challenges for the EU in today's global context is that of terrorism and the counter terrorism measures and programs that the EU institutions need to develop in the following years.

According to Business Insider terrorism can be quantified both on short and long term []. This is due to the fact that terrorist attacks are considered to always have an immediate impact on short-term markets. Investors lose interest in markets that are susceptible to terrorist attacks and thus a drop in economic growth can be observed in countries where terrorist attacks have occurred.

Such is the example of Turkey. In a study by BBC Turkey has accounted for a decrease of up to $30 \%$ in its tourist market, due to increasing conflicts with Russia (one of Turkey main foreign investors in terms of $\mathrm{FDI}^{3}$ ) and due to terrorist attacks in major cities and near the Syrian border. In the following table, an example of the changes in tourist arrivals can be seen:

\footnotetext{
${ }^{3}$ Foreign Direct Investments.
} 
Figure 5. Tourism Decline in Turkey

Tourism in Turkey in decline

Year-on-year change in arrivals, \%

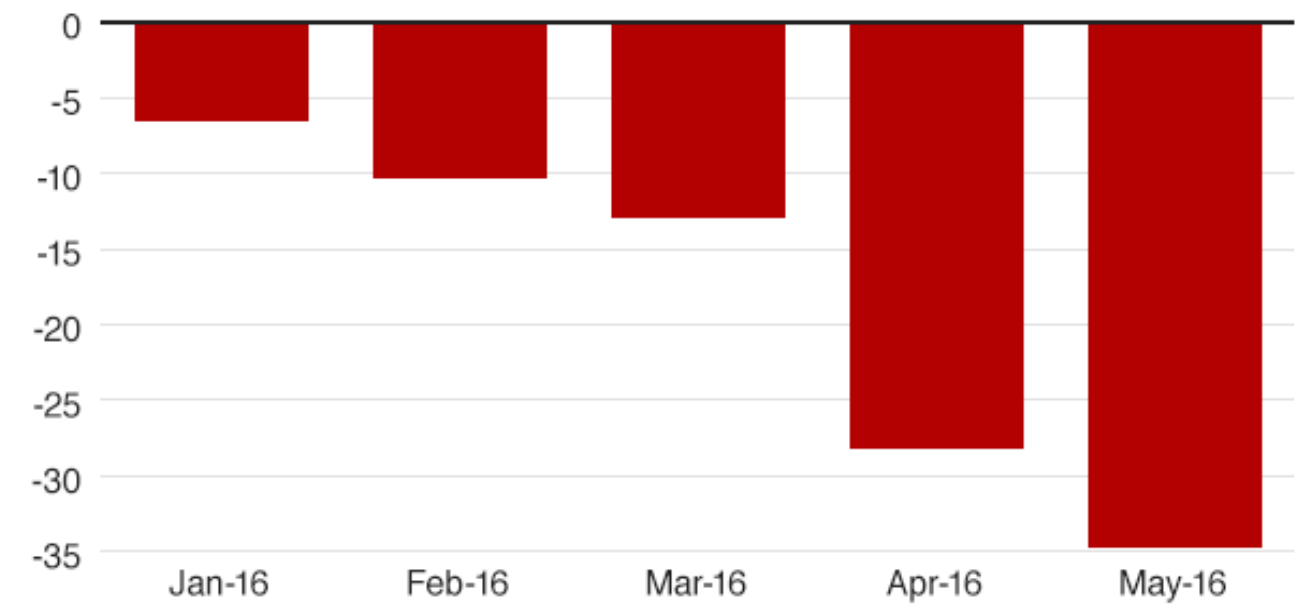

Source: Turkey's ministry of culture and tourism

Source: $w w w . b b c . n e t$

It is common for consumers to cancel travel plans in wake of a major attack, and by doing so impacting general revenues from restaurants, hotels, airlines or travel agencies. Just like in Turkey, hotels in Belgium have been the subject of canceled reservation to percent of up to $40 \%$ in just one weekend following the attack in the Brusseles Airport of Zaventem on the 22th of March, 2016.

Repeated violence and the possibility of future attacks can affect markets even more, as it has happened in the case of Egypt. Taking into consideration that Egypt is a country that depends on tourist revenues, the decision of UK and Russia to halt flights to the country following the terrorist attack that saw the downing of the a Russian plane on the $31^{\text {st }}$ of October, 2015 in Sinai, it has been estimated that Egypt might lose up $280 \$$ million per month due to cancelations of flights, hotels and restaurant reservations. ${ }^{4}$

Stronger economies like those of the EU and USA tend to not be affected on short term by terrorist attacks, as is the example following 9/11 in the US, when the GDP dropped by only half a percentage point, while the stock market had been barely affected at all (Bryan W., Roberts, 2009). The same can be said for France, whose CAC-40 Index ended just $0.1 \%$ lower following the Paris attacks on the $13^{\text {th }}$ of

\footnotetext{
${ }^{4}$ http://www.bbc.com/news/world-europe-34797165
} 
November 2015 and for the UK whose markets bounced right back after the London suicide attack in 2005. These countries benefit from a strong economy and from a general belief in well developed security policies. There is a question of the effects that terrorist attacks might have on a long-term in terms of economic development and security challenges.

There is a general belief that developed and prosperous nations bounce back much quickly and therefore their economy will affected because of resilience and consumer confidence that overshadow any given setbacks.

Studies show that this happens in the tourism industry for example, where instead of abandoning travel plans, tourists instead postpone their agenda for a future period of time and by doing so, consumption is not damaged on long-term (Buttonwood, 2015). This is not however the case for countries that experience frequent terrorist attacks. Here the long-term economic implications are severe. Such is the case of Syria and Iraq for example. Terrorist attacks have damaged these countries' economies, causing unemployment, inflation or labor migrations.

Other less obvious economic costs also must be taken into consideration. Military and police force expenditures increase in case of possible terrorist attacks. The same happens when expenditures are diverted to extra surveillance or policing instead of the investment sector. Thus a greater spending on unproductive activities because of counterterrorism measures can unbalance the national economy in some countries by dragging the growth of the GDP. When taking the GDP into consideration studies has shown that overtime friction in the economic system have visible effects on economic growth. Such is the example of Israel, a country that is confronted by terrorist attacks and violence. It has been estimated that the GDP would have been $8.6 \%$ higher for a period of ten years ${ }^{5}$, had there been no fear of possible violence and attacks (Ross, 2015).

It is for this reason why some experts consider that an increase of border controls in the Schengen area following the Paris attacks would be a mistake, as with inflict complex economic challenges for the EU on a long period of time. In a European Union where convergence between member states is increased and where trade and common investments in industries are at a very high level, restrictions in border traffic and transfer would have negative long-term effects.

It is for this reason that overall effects of terrorist attacks are likely to be negative on national economies, even though it is highly difficult to calculate the exact impact of these effects. There is obviously the physical and emotional impact of terrorism, but besides that economic growth is threatened as well, because a growing complex security environment means an increase in unproductive costs. In conclusion, nations must ensure a balance between defense expenditures and social investments.

\footnotetext{
${ }^{5}$ The study mentions the 1994-2003 time frame.
} 
This can be achieved by managing an efficient expenditures system that takes into consideration all challenges, both economical and security-linked that the EU has to confront in this new global context.

\section{Legal and Illegal Immigration in the EU and its Implications on European Security}

The topic of Immigration inside the EU has to be divided into two different areas. One area is that of Legal Immigration, that has been a part of the EU's agenda ever since the organization was formed in 1958. The other area of interest is that of Illegal Immigration, a challenge and an issue for the EU which has increased in the period of 2013-2016 because of the refugee's crisis and the increasing number of illegal immigrants arriving by several routes from Asia and Africa into EU territory.

Historically there have been many challenges for the EU in terms of migrations. Following the collapse of the Soviet Union, one concern became that of legal immigrants travelling from East to West, from Eastern European countries to countries with powerful economy in order to get higher wages and increase their social welfare. The migration from East to West has been a challenge for EasternEuropean countries even before they managed to enter in the European Union in the late 90's or after the new millennium started. An issue was inside the powerful Western European countries who considered that Eastern-European immigrants would drive wages down by accepting lower wages. This issue is still valid today, being one of the reasons behind Great Britain's campaign of leaving the EU.

However the last two decades have demonstrated the benefits that legal migration inside Europe brings to member states as skilled immigrants have helped economies develop and innovate, labor markets have strengthened while for receiving countries the general result has been an increase in economic growth. [] This is however not the same case for illegal immigrants. Illegal immigrants are usually low skilled workers, have fewer chances in obtaining legal employment, face language barriers and therefore they cannot benefit from the European welfare system. They often become subject to organized crime, human trafficking, violence and even terrorist acts. European Institutions have several challenges in managing illegal immigration as there is an increase in this type of immigration following the refugee crisis that started in Europe since 2014. This refugee crisis is due to the war in Syria, poverty in Africa and social insecurities in the Middle East.

Several migration routes on land and on the sea have been developed by the illegal immigrants, with over 220000 migrants reaching the EU in 2014. The European Commision's agency for Border Control, Frontex cannot handle the increasing flows. These flows have affected the Schengen Space, with member states closing their border, and by doing so bringing major negative economic effects in transport, tourism and trade. A lack of personnel in border control has also been identified in the EU Schengen Area, and the External Borders suffer from poor surveillance. 
Having to deal with all these challenges as well as divergent border policies by member states, the European Commission has decided to strengthen Frontex, by creating at the end of 2015, a new border agency, called the European Border and Coast Guard. Its mission will be to assure security for borders inside the EU, for Schengen Area borders, as well as the EU's external borders. The agency will overlook all immigrants' routes, be it on land or sea, secure residents in the borders area and assure safe passage through the final destination for legal immigrants and refugees. In the same time it is the European Commission's mission to increase the return rate for both refuges who are to travel back to their countries of origin or for illegal immigrant who did not receive asylum.

\section{EU Economic and Political Relations with Russia}

From an economic point of view Russia is the third trading partner of the EU and the EU is the first trading partner of Russia. While EU export to Russia are dominated by machinery, chemicals, medicines, agricultural products and transport equipment, EU imports from Russia are dominated by raw materials, like oil and gas.

Before the 2007-2009 crisis trade between the two economies had been on an increasing trade. During the crisis Russia adopts unilateral economic measures that had an even more negative impact on the EU-Russia trade. However during the crisis, Russia kept its trade relations a high level with some member states like Poland. After the crisis ended, in 2010, mutual trade resumed with record levels in growth in 2012. Following the conflict with Ukraine, dissensions between Russia and the EU appeared. For this reason the EU has drawn economic sanctions on Russia that decreased the number of trades between the two economies.

The economic sanctions have had a negative impact on Russia's economy, as EU is the most important investor in Russia. FDI from the EU into Russia's stock represent up to $75 \%$ of Russia total FDI as shown in Figure 6.

However, even though the economic sanctions from the EU have deteriorated relations between the two economies, Russia and the EU depends on one other when it comes to the export of energy. Over the years there have been several attempts by EU member states to develop pipeline projects, some in advantages and some in disadvantages in accordance to the relations between Russia and the EU.

Such is the example of Nabucco, which would bring natural gas from Azerbaijan, through Turkey into the European Union, and by doing so avoiding Russia and reducing the dependency that the EU has on Russia's natural gas.

Russia has proposed a different pipeline, the project entitled South-Stream that would bring natural gas from Russia through the Black Sea and into the EU territory. The project has been abandoned in 2014, but after several negotiations with Turkey a different project that involves the transport of natural gas from Russia, through 
Turkey and further on into Europe will be planned and could become a rival for the Nabuco pipeline.

In terms of trade, the European Union has always been an ally of Russia and has offered its support when Russia entered the World Trade Organization in 2012. The EU found that stronger economic partnerships could be developed between the two economies, if Russia became a member of the WTO. However, until 2014, Russia had still refused to adopt several measures as part of the country's commitment to the WTO.

Figure 6. EU-Russia Trade

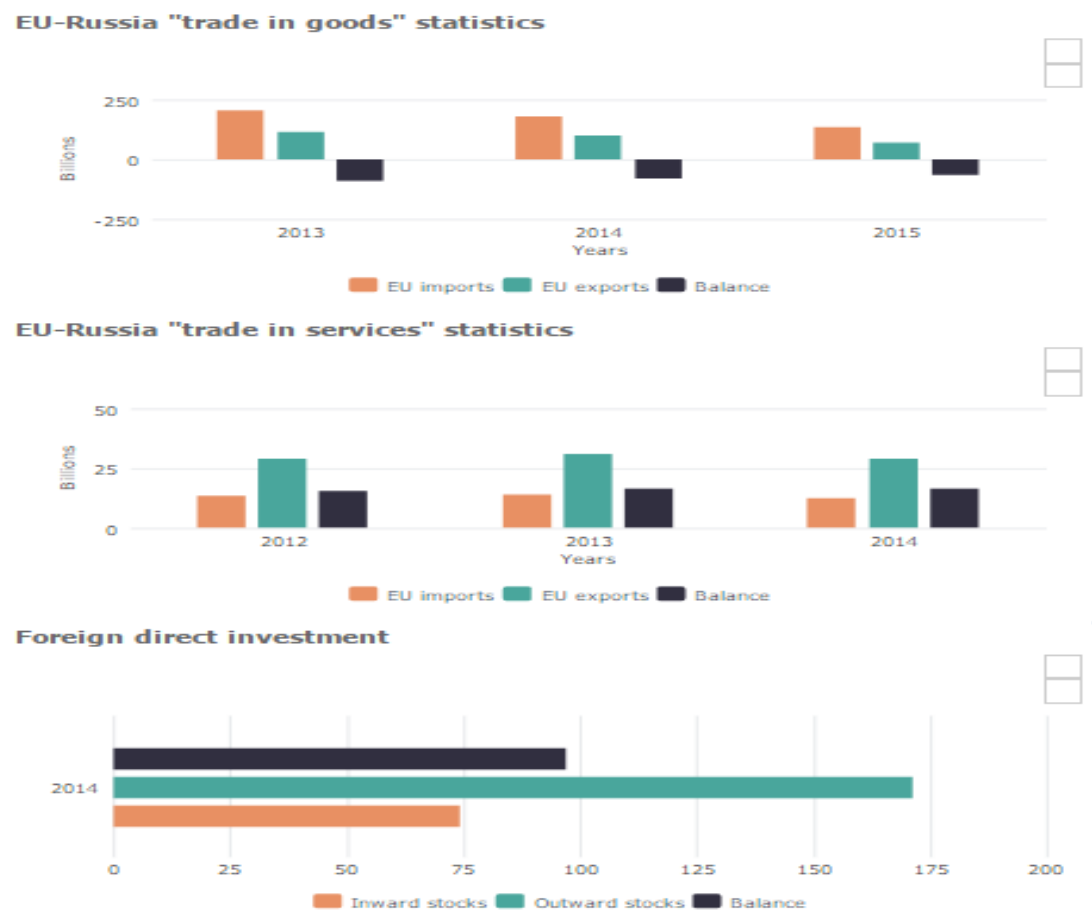

\section{Source: Eurostat}

The relations between Russia and the EU are an example of how security challenges can have a negative impact from an economic point of view. Even-though economic relations between the two parties are significant as presented earlier security issues and decisions by Russian institutions have deteriorated the relationship between the two economies. The following are examples of security incidents that can be considered to have had an impact on the economic relations between Russia and the EU. 
In April 2015, France sources indicated that a cyber attack on the French television channel TV5 Monde that was initially attributed to the terrorist group ISIL had actually been a cyber attack leading to Russia. In May, the same year, a cyber attack shot down the German Bundestag's servers. The Federal Office for the Protection of the Constitution claimed that the attack was delivered by a group of hackers that were likely to be under the guidance of the Russian state.

In January 2016, in the context of the immigration crisis in EU, Finnish authorities reported that Russia was enabling migrants to enter finish territory in trying to create concern with the resident population.

During the Brexit campaign, Russia was accused of supporting the United Kingdom's withdrawal from the EU, by use of its channels, such as Russia Today and also through some of its institutions such as the Russian Federation embassy in London. Following the successful bre-xit campaign, Nigel Farage, the leader of the out-campaign was offered a position on one of Russia's Today premiere shows, which he declined.

The lack of trust in terms of security, the possibility of a cyber-warfare between Russia and the EU and Russia's military actions in the past have damaged the economic relations between the two entities. As the two share common economic interests, depending on another in terms of trade, energy and foreign direct investment it is necessary for Russia to demonstrate that it can create a safe security environment in Europe. By doing so, the EU will be able to restart its economic relations with the Russian Federation so as to assure that both economies and benefit from economic growth like they had in the past. The continue lack of trust because of security issues would only increase the instability in economic relations between the two entities leading to economic lass for both parties. European Institutions have to take into consideration the relationship with Russia, in order for them to create a balance when taking decisions regarding to Russia's economic and security actions.

\section{Security Implications of Economic Development Differences between EU Member States}

Studies have shown that convergence has increased inside the EU and that even the so called newly-entered states are experiencing economic growth (Albu,2015). Though this is true, sizeable differences between members states still exists, in terms of monetary and fiscal policies, social and welfare policies and other politically directed strategies.

Figure 7 presents an estimation for the year 2020, predicting the convergence for all member and possible member states, in regard to economic growth. Former-newly entered states like Romania, Poland and Slovenia will present a similar trend with the likes of Germany and Sweden. Countries that are not current members of the EU, 
but have shown interest in joining the Eu will also converge in economic growth with current EU members. Such are the case of Serbia or Ukraine.

Figure 7. GDP per Capita

\section{GDP Per Capita 1990-2020}

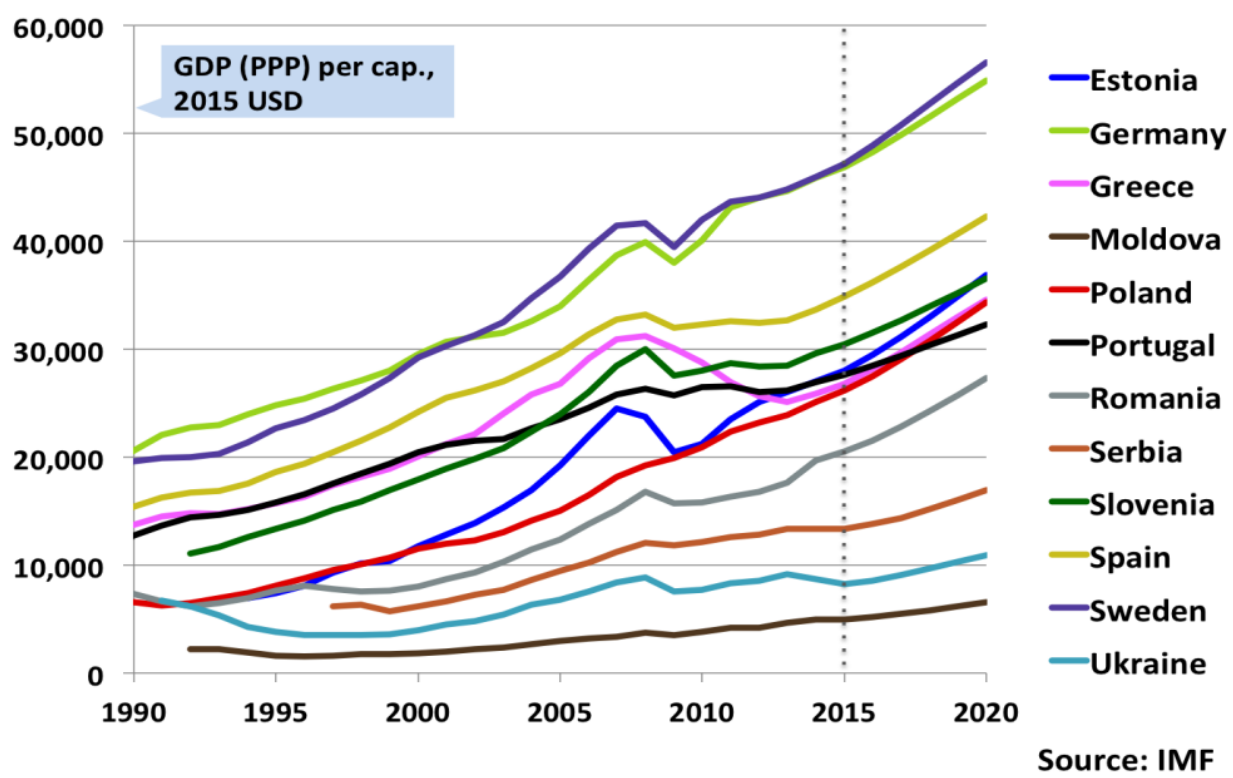

Source : IMF

http://ec.europa.eu/economy_financeleuro/adoption/convergence_reports/index_en.htm

However following the Brexit, questions about the unity of the EU have been raised. It has become clear that forging unity as Europeans has never been so difficult. Due to the challenges that the EU is confronted with, unity has also never been so vital or so urgent. Institutions must cooperate at an entire different level and economic gaps between member states must be reduced. The immigrant crisis of 2015 has brought a question regarding policies inside the EU and the willingness of member states to cooperate on all matters on hand. Even though security issues are challenging, as it has been presented in the previous chapter, economic challenges remain the most important cause for dissensions between member states. The recent example of Greece, the austerity measures proposed by Germany and European Institutions on Eastern-European countries have created distrust and even signs of euro-skepticism in some states.

The fact that leading member states like Germany and France also share different economic policies has been a downfall for the EU. For example's Germany's austerity policies are very different from France's socialized economic policies. Following the Brexit, discussions about the two-speed Europe have become of interest again. The possible failure of the Euro-zone system is taken into 
consideration, even-though there are still member states that have applied into the Eurozone. In order for the EU achieve economic cohesion, countries that have a growing GDP, like Romania and Poland can become a stronger partner for developed member states like Germany and France. Meanwhile, if its economic indicators will continue to grow, Italy will become the first choice in replacing Great Britain as one of the key players in the EU's economic development alongside France and Germany.

For this reason in order for the EU to function as a unity, economic cohesion is needed. It is up to the European Institutions to eliminate economic differences between member states. Other institutions need to be reformed in order to assure a strengthened unity. Such is the example of the Schengen Area, where the European Commission has developed a new border agency to replace Frontex, and EU member states have been encouraged to apply in order to be members of the Schengen Area.

\section{The Challenges of the Organized Crime to EU Security}

There is no universally agreed definition of organized crime, but two theoretical models stand out from the literature: the first is referred to as the mafia model, viewing organized crime in the form of an organized group of criminals, bound by strict codes of conduct, with a strict hierarchy, operating in a business-like manner and resulting from and taking control over a society. The second model considers organized crime from a social systems approach, referring to a looser set of networks, with a less rigid hierarchy, less stable, "with organized criminal actors as economic rationalists, who carry out a cost-benefit analysis of sectors of the illicit market'(Albini, 1971). The reality is often more complex, featuring a mixture of the two, with national or international links in the criminal activity, underlined sometimes by clear ethnic links in some illegal situations and sometimes characterized by a bureaucratic and business oriented feature.

Organized crime carries important economic costs, both direct and indirect, that are difficult to accurately quantify. A study on the economic, financial \& social effects of organized crime in the EU estimated some minimum identifiable direct economic costs, of just a few of the illegal activities, whose amounts prove to be extremely important: cost of human trafficking - €30 billion, fraud against EU in the form of cigarette smuggling - $€ 11.3$ billion, in the form of VAT/MTIC fraud - $€ 20$ billion and in the form of agricultural and structural funds - $€ 3$ billion; the fraud against private EU individuals - $€ 97$ billion; the result of unrecovered motor vehicle theft $€ 4.25$ billion; payment card fraud - $€ 1.16$ billion(The Economic, Financial \& Social Impacts of Organised Crime in the EU, 2013). To this, we can add the costs involved in fighting the organized crime, with a conservative estimation at EU level of $€ 210$ million (Europol/Eurojust/EMCDDA/Frontex only). The European Monitoring Center for Drugs and Drug Addiction has estimated, based on the estimates provided by EU members states for the 10 years, that drug-related public expenditure are 
between $0.01 \%$ and $0.5 \%$ of gross domestic product (GDP), with health interventions representing between $15 \%$ and $53 \%$ of all drug-related public expenditure(European Drug Report Trends and developments, 2016).

Still, we have to keep in mind that the numbers are a lot higher when we consider that health interventions are only the tip of the drug use iceberg, as the costs of the drug addiction treatments are related to what governments can allocate for drug treatment, they do not reflect its impact on users or society, such as increase in infectious diseases, such as HIV and hepatitis C.

The mafia-type organized crime can be a serious national problem for some EU members (such as Italy or Bulgaria), but can not be considered a EU-wide problem. Other types of organized crime are proving to be a huge challenge to the EU security, with serious economic implications, through the reorientation of loosely connected networks of organized groups that previously were involved in smuggling goods, towards the lucrative business of smuggling people. Interpol identified more than 250 hotspots for migrant smuggling, within and outside the EU. Alarmingly, according to the Interpol report, more than $90 \%$ of the migrants coming to the EU were introduced through the activities of a criminal network (MIGRANT SMUGGLING NETWORKS Joint Europol-INTERPOL Report, 2016).

The criminal networks are increasingly attracted to facilitating migrant smuggling by the huge profits (an average USD 5 to 6 billion turnover in 2015), relatively low costs and high demand from the refugees in conflict areas, especially over the Mediterranean. Profits from smuggling activity are now approaching those from drug and arms trafficking; in Lybia, migrant smugglers can have a profit of $\$ 150,000$ on a boat crowded with 150 migrants, while in Turkey larger old cargo ships can generate almost $\$ 4$ million per trip in profits (Dettmer, 2015). The illegal migration (and implicitly the people smuggling activity) are expected to increase in future years, and the Interpol expects an increase take-over of the smuggling activity from larger, more organized criminal networks, increasing the security problems at the level of the EU.

Besides the security and economic challenges for the EU already discussed related to illegal immigration, often the migrants smuggled within the EU are potential targets for labor or sexual exploitation, given their vulnerable status related to lack of identification, work and housing opportunities, not knowing the language etc. They may be also forced into criminal activities or recruitment of other potential clients, by the smugglers that brought them to the EU, with unaccompanied minors as prime victims.

Considering the serious security implications of this type of organized crime, EU member states should take decisive measures to improve the cooperation on the exchange of information on migrant smuggling criminal networks and to increase the effectiveness of INTERPOL and Europol capabilities provided. 


\section{Conclusions}

The EU member states need to commonly bring to date and improve the existing legal and institutional framework to effectively fight common challenges, in a realistic manner, adapted to the current economic, security and political realities, within and outside the EU. A better correlation between the EU common policies and the member states policies is needed, together with an improved connection with the civil society, in order to prevent the increase of the anti-European trend in the member countries. In this respect, the concerns of the population in the member states (such as the impact of migration and terrorism, the impact of the economic crisis, the concerns regarding unemployment etc) should be better addressed in the common EU policies.

The European Union should take specific steps towards the clarification of the dimensions and directions of a common security and defense policy. Even if the concept of an "European Army" is still far away, the common security and defense policy needs to be addressed not only in general political terms, but also in more specific military and financial terms, in order to improve the effectiveness of the member states defense expenditures, improve cooperation, develop common European capabilities and avoiding their duplication. Although the trend for increased defense spending appears to continue at the level of many EU member states, the total defense spending is still not enough to support truly autonomous capabilities. In the context of a common EU and NATO membership, many member states may not be willing to increase further the defense spending. Still, the aim should be for an increase in the output of the existing level of defense spending and savings through a better distribution of the defense funds across the EU, engaging in collaborative programs and increased cooperation and interoperability.

In order for the migration process to function in the interest of member states, the current process of integration and asylum should continue and become even more efficient. Still the return process, that has proven to be ineffective so far, should be reorganized in order to assure member states that all illegal immigrants are returned to their countries of origin. Throughout this paper it has been stressed out that one of the major challenges for the Schengen space and for border security agencies is represented by the low percentage in return of immigrants. This process must be managed correctly in order to create a balance between the flow of legal immigrants entering the EU and a more efficient return percentage for the illegal immigrants.

Updating FRONTEX through the development of a new security agency represents a potential way for the EU to improve its border management process. By granting it larger power within the Schengen space and outside it, by allowing it to take over some of the functions from the member states, a more effective management of immigration could be achieved, at the EU institutional level. This example should be followed also in other areas and in European institutions dealing with social or security policies, in order to develop new, more effective, agencies and institutions. 
The European Union needs to reform, following two key events that generate increased costs for member states. The first is the British exit from the EU (Brexit). The second is the new European security context, whose challenges we presented in this paper. From this point of view, it is necessary that certain countries such as Italy, Poland or Romania to gain a more important role in the European Union. For this to happen it is necessary to decrease the economic gap between the development levels of the member states, and as a result we can say that EU's security challenges cannot be solved without addressing also its economic challenges. Also, considering EU's relations with other neighbors, it is very important to improve its economic relationship with Russia and this cannot be done separately from a more coherent common foreign policy.

In order to overcome the challenges outlined in this paper, the European Union needs to use a comprehensive approach, through policies in many areas (economic development, defense, terrorism, cyber security, organized crime, hybrid threats, external border management, external relations etc). The success of this approach depends first of all on the ability of the EU to overcome the inertia and lack of political will that has characterized the EU policy in the latest years. The EU member states need to seriously discuss and reconsider their common European identity and to take decisive measures to overcome the security challenges. Independent measures taken by individual state members, not correlated with a common EU approach, are not going to contribute to a long term solution to the challenges.

\section{References}

Emcdda.europa.eu, European Monitoring Centre for Drugs and Drug Addiction. 2016. European Drug Report Trends and Developments, Available at http://www.emcdda.europa.eu/edr2016, [Accessed at 21.05.2016].

Europol.europa.eu, Europol. 2016. Migrant Smuggling Network Joint Europol-Interpol Report, Available at www.europol.europa.eu/sites/default/files/documents/epip_report_executive_summary, [Accessed at 12.06.2016].

Council of the European Union. 2014. Recommendations on the Note from the High Representative on options for improvement of the financing of civilian and military missions and operations, Available at http://www.statewatch.org/news/2014/aug/eucouncil-civilian-military-missions-12269-14.pdf, [Accessed at 10.06.2016].

Europarl.europa.eu, European Parliament. 2013. The Economic, Financial \& Social Impacts of Organised Crime in the EU, Available at http://www.europarl.europa.eu/RegData/etudes/etudes/join/2013/493018/IPOLJOIN_ET(2013)493018_EN.pdf, [Accessed at 09.06.2016].

Europarl.europa.eu, European Parliament. 2016. The future of EU defense research, pp 29, http://www.europarl.europa.eu/RegData/etudes/STUD/2016/535003/EXPO_STU(2 016)535003_EN.pdf, [Accessed at 09.05.2016] .

Europarl.europa.eu, European Parliament. 2016. The future of EU defense research, pp 85, http://www.europarl.europa.eu/RegData/etudes/STUD/2016/535003/EXPO_STU(2 016)535003_EN.pdf, [Accessed at 09.05.2016].

Eur-lex.europa.eu, The mechanism for financing military operations Athena, 2004-2007, 
Available at http://eur-lex.europa.eu/legal-

content/EN/TXT/?uri=URISERV\%3Al3328, [Accessed at 15.05.2016].

Consilium.europa.eu. 2003. A Secure Europe In a Better World, 2003, European Security

Strategy, Available at https://www.consilium.europa.eu/uedocs/.../78367.pdf,

[Accessed at 20.05.2016].

Ec.europa.eu, Aerospace and Defence Facts and Figures, 2014-2016, European Commission,

Available at https://ec.europa.eu/growth/sectors/defence_is, [Accessed at 24.05.2016].

Albu, L. 2015. Institute for Economic Forecasting, Interactions between financial markets and macroeconomic variables in EU markets: a nonlinear modeling approach, research project .

Buttonwood. 2015. Why terrorism has a limited impact on markets, the Economist, [online], Available at http://www.economist.com/node/21678527/comments, [Accessed at 10.09.2016].

Dettmer, J. 2015. Europe's Migration Crisis a Boon for Organized Crime, Available at http://www.voanews.com/a/europe-migration-crisis-a-boon-for-organizedcrime/2952482.html, [Accessed at 08.09.2016].

Ec.europa.eu, European Commission, European Development Fund (EDF), Available at http://ec.europa.eu/europeaid/funding/funding-instruments-programming/fundinginstruments/european-development-fund_en, [Accessed at 14.09.2016] .

Albini, J.L. 1971. The American Mafia : Genesis of a Legend, New York, Irvington.

Knell, Y. 2015. Egypt tourism teeters after Sinai plane crash, BBC News, [online], Available at http://www.bbc.com/news/world-europe-34797165, [Accessed at 10.09.2016] .

Liapis, K., Rovolis, A., Galanos, C. and Thalassinos, I.E. 2013. The Clusters of Economic Similarities between EU Countries: A View Under Recent Financial and Debt Crisis. European Research Studies Journal, 16(1), 41-66.

Marrone, A., De France, O., Fattibene, D. 2016. Defense Budgets and Cooperation in Europe, pp.8, Available at http://www.iai.it/sites/default/files/pma_2.pdf, [Accessed at 10.08.2016].

Mogherini, F. 2016. Shared Vision, Common Action: A Stronger Europe- A Global Strategy for the European Union's Foreign and Security Policy, Available at https://eeas.europa.eu/top_stories/pdf/eugs_review_web.pdf, [Accessed at 08.09.2016].

Mogherini, F. 2016. Shared Vision, Common Action: A Stronger Europe- A Global Strategy for the European Union's Foreign and Security Policy, pp. 44 Available at https://eeas.europa.eu/top_stories/pdf/eugs_review_web.pdf, [Accessed at 08.09.2016] .

Mogherini, F. 2016. Shared Vision, Common Action: A Stronger Europe- A Global Strategy for the European Union's Foreign and Security Policy, pp. 45 Available at https://eeas.europa.eu/top_stories/pdf/eugs_review_web.pdf, [Accessed at 08.09.2016] .

Mogherini, F. 2016. Shared Vision, Common Action: A Stronger Europe- A Global Strategy for the European Union's Foreign and Security Policy, pp. 49 Available at https://eeas.europa.eu/top_stories/pdf/eugs_review_web.pdf, [Accessed at 08.09.2016] .

Pociovalisteanu, M.D., Thalassinos, I.E., Tirca, A. and Filho, L.W. 2010. Trends and 
challenges in the energy sector of Romania in the post-accession to the European Union. International Journal of Environmental Technology and Management, 12(1), 3-15,

European External Action Service. 2008. Report on the Implementation of the European Security Strategy - Providing Security in a Changing World, Available at https://europa.eu/globalstrategy/en/report-implementation-european-securitystrategy-providing-security-changing-world, [Accessed at 20.08.2016].

Roberts, B.W. 2009. The Macroeconomic Impacts of the 9/11 Attack: Evidence from RealTime Forecasting, Available at https://www.dhs.gov/sites/default/files/publications/Macroeconomic\%20impact $\% 20$ 9_11\%202009.pdf, [Accessed at 30.08.2016].

Sipri.org, Stockholm International Peace Research Institute, SIPRI Military Expenditures Database. 2016. Military expenditure by country, in constant (2014) US\$ m., 19882015, Available at https://www.sipri.org/databases/milex, [Accessed at 15.07.2016].

Storkin, R.A. 2015. The Hidden Costs of Terrorism, The New York Times [online], Available at https://www.nytimes.com/2015/11/17/business/dealbook/the-falloutfrom-attacks-is-measured-in-more-than-stock-markets.html?_r=0, [Accessed at 20.08.2016] .

Thalassinos, I.E. and Pociovalisteanu, M.D. 2009. The Structural Funds and the Economic and Social Cohesion Process. Annals-Economy Series 1, 313-330.

Thalassinos I.E. and Dafnos G. 2015. EMU and the process of European integration: Southern Europe's economic challenges and the need for revisiting EMU's institutional framework. Chapter book in Societies in Transition: Economic, Political and Security Transformations in Contemporary Europe, 15-37, Springer International Publishing, 